\title{
On Developing National Music Education among Higher Vocational Students
}

\author{
Na Zhou \\ Jingzhou Institute of Technology, Jingzhou, Hubei, 434020, China
}

Keywords: higher vocational education; national music; education

\begin{abstract}
In view of the continuous advancement and popularization of quality education and new curriculum reform, the music teaching in higher vocational colleges is paying more and more attention to the integration of the students' ethnic music education content, so as to promote the overall development of higher vocational students' overall quality. Therefore, in the higher vocational music teaching, students should understand and master the contents of local national music culture in China more comprehensively, so as to stimulate the music art emotions of higher vocational students. This paper gives an overview of folk music, analyzes the development of China's national music culture, expounds the urgency of introducing ethnic music education among higher vocational students, and puts forward main methods of developing national music education among higher vocational students.
\end{abstract}

\section{Introduction}

Chinese traditional culture has a long history and has accumulated a lot of essential content for thousands of years. Higher vocational students are both responsible and obliged to protect traditional culture, and they should also promote traditional culture, including ethnic music. Since the implementation of reform and opening up, China's overall national strength has been greatly improved. However, compared with economic development, our country's national culture has also been developing synchronously, especially some young people are very keen on Western culture, which has led to the challenge of the inheritance of our country's traditional music culture. To effectively reverse the fact that China's cultural soft power lags behind developed countries in the West, it has become an important task for higher vocational students in the new era. Therefore, at present, it should be an in-depth analysis of the current status of China's vocational music education and put forward reasonable methods to improve, so as to be able to better improve the quality of higher vocational music teaching.

\section{Overview of Ethnic Music}

National music can be mainly elaborated from two perspectives, broad and narrow sense. Broadly speaking, national music mainly refers to the individual's own music, that is, the music that is shared and inherited by the national music and its culture. The national music in the narrow sense mainly refers to the form of a certain national music that is rooted in the daily production of various ethnic groups. Each ethnic group has its own ethnic characteristics. This is a common feature among its own ethnic groups, but it has a certain personality for foreign nationalities. This is the uniqueness that has arisen in the historical inheritance and development of various ethnic groups. culture. Every ethnic group has its unique lifestyle, religious beliefs, and modes of thinking. It is precisely because of the above factors that it constitutes the characteristics of national music. Therefore, ethnic music can be understood as a musical form with ethnic characteristics and a certain value system. At present, the national music in our country has gradually developed into the concept of conventional conventions. It usually refers to the portion of traditional music that has been passed down from generation to generation and is loved by the people. 


\section{The Development of Chinese National Music Culture}

Because our country has a vast territory and a very large number of ethnic groups, the national music culture also has a diversity of features, that is, it has very rich resources in ethnic music. However, considering the current actual situation, only a few ethnic music cultures can be inherited and developed in the society. There are even some folk arts that have problems with faults or interruptions and face the threat of complete severance. For example, the traditional folk music cultures such as guqin art, Kunqu art, and Naxi ancient music art have gradually disappeared from the eyes of modern people. This is not only the disappearance of a certain type of music works, but also a fault of the inheritance of folk music culture. In recent years, due to the influence of foreign culture, the number of national traditional music works played by our country's new media and other traditional media has dropped sharply, while rock music and pop music have become popular. At the same time, teenagers will be greatly affected by pop music in Hong Kong and Taiwan, and cultures in Korea and Korea, but little is known about traditional music culture in China. Even among academic education, there is a lack of related content in traditional music teaching, so that the foreign culture spread on the media or on the Internet has had a great impact on the thinking of higher vocational students. Even if the music culture of the country has been studied in school music education, the teaching methods are too traditional and blunt, which can also lead to poor teaching results. Faced with the fierce impact of Western culture, China should form a sense of responsibility for cultural crisis in school education as soon as possible, and continue to strengthen the inheritance and development of the culture. For the government, it is necessary to continuously strengthen the construction of cultural industry projects and form a unique local cultural brand. Schools should also continue to strengthen the education of ethnic music and culture so that students can form a scientific and correct ideology through systematic learning.

\section{The Urgency of Introducing Ethnic Music Education in Higher Vocational Students}

The first is to promote the cultivation of composite talents in higher vocational colleges. For higher vocational schools, it is the purpose of running a practical and skilled talent for the society. However, at present, all higher vocational schools do not pay enough attention to the development of the overall quality of students, such as morality, physical beauty, etc., but only pay attention to the study of professional skills. Higher vocational teachers also pay more attention to the teaching of professional knowledge. Under this circumstance, if national music education can be implemented in higher vocational education, it will be very beneficial to improve the overall quality of the vocational college students so that more talents can be trained.

The second is to promote the inheritance of the national music culture. According to the research of relevant experts, the information industry and the art industry will be the two largest industries in this century, and the role of modern information technology in people's daily life has been greatly reflected. The high-tech products such as the Internet and mobile phones used by modern people have become indispensable items in life. On the other hand, the art industry has not really formed its own scale. Because science and technology cannot be separated from art, the art industry will certainly rise rapidly in the face of rapid changes in science and technology. The production of industrial products will also develop toward the trend of artistic products under the influence of science and technology. After more than 5,000 years of historical vicissitudes, China's ethnic music and cultural resources have been very rich, but have not yet been fully utilized in the tide of economic development. In the next step, the art industry will inevitably develop into a new growth point, and ethnic music will provide a very powerful spiritual force for the development of science and technology and the development of digital powers.

The third is to build the multi-cultural values of Ruidong higher vocational students. In the early music education system of the student group, it is impossible to rapidly teach the essence of our traditional music culture, so as to avoid the students entering the blind area for learning the national music in the future learning and growth. The development of national music education for the group 
of vocational students can promote the integration of national consciousness and continuously promote the national culture education for the students of the vocational colleges. The national music education can strengthen the master's students' mastery of national music, thus providing a solid guarantee for the inheritance and dissemination of our country's national music culture. Of course, national pride and patriotism can also be cultivated through ethnic music education. Based on the study of ethnic music, divergent thinking patterns can be established so that higher vocational students can absorb the advanced music elements of other countries on the basis of learning the national music, continuously improve the flexibility of thinking, and can also create music. On the rise. The study of diversified cultural values and national music is not completely antagonistic. Instead, it is able to maintain complementarity, so that higher vocational students can more and more agree with the music culture of different nationalities. In carrying out the music knowledge thematic study, we should effectively avoid the self-centered bad phenomenon, and effectively help the vocational students form a diversified music culture development concept, and adopt a correct attitude to diversify the environment.

\section{The Main Methods of Developing National Music Education in Higher Vocational Students}

The first is to include excellent national music in the curriculum system of higher vocational students. In order to be able to effectively improve the quality and ability of the vocational college students, the most ideal means is to infiltrate the national music teaching curriculum into the curriculum they have learned. Teachers should set relevant courses according to the teaching goals, and they should also allow students to learn more about the above ethnic music knowledge in the lower grades. For those students who are more interested in ethnic music, higher vocational colleges may set up elective courses so that the students of higher vocational colleges can have a good opportunity for continuous learning. At the same time, it is also necessary to comprehensively integrate popular teaching with in-depth teaching, so as to create a set of mature and perfect national music teaching mechanisms, and allow all students to have the opportunity to learn. In carrying out the teaching of basic courses, it is necessary to use inspection methods to check the effectiveness of the learning of the students of higher vocational schools, and to enable our national musical heritage to be fully promoted.

The second is to establish specialized talents for music teachers. In order to maximize the level of music education and teaching, higher vocational schools should create specialized teachers and talents. In the main work links, the following points should be addressed: First, a music teaching and research group should be established so that professional music teachers can issue targeted teaching plans based on various teaching objectives. The second is to reasonably arrange music teachers in the school based on the number of students, and to carry out strict assessments when selecting teachers, and to select the most appropriate music teacher based on the assessment results and student satisfaction evaluation. Finally, teachers should take responsibility for the investigation of students' music learning status, and conduct comprehensive explorations of problems encountered by students in the classroom, and then introduce specific teaching plans to effectively meet the students' needs for ethnic music content. Learning needs.

The third is to implement various activities related to the national music culture. The creation of a good ethnic music learning environment is an important way to improve the quality of national music teaching, inspire learning, and increase its comprehensive ability. Therefore, music teachers should implement more abundant activities in teaching, and then link up with classroom teaching in the future, so that students in vocational colleges can also feel the strong influence of national music in their lives. At the same time, higher vocational colleges can also hold lectures, inviting ethnic music researchers to teach relevant knowledge in advance, and allow all interested students to take part in it, so that they can continue to improve their music performance and synthesis. Quality.

The fourth is to carry out artistic practice. Compared with other music teaching systems, ethnic music teaching should strengthen the innovation of teaching methods and teaching design. Music teachers should pay full attention to the changes in educational concepts and teaching models, use 
scientific control of classroom teaching methods, rationally interpolate representative ethnic music works into the classroom education system, and use teaching appreciation to broaden higher vocational education. Students' vision. At the same time, in specific teaching, music teachers should also use teaching practices, use different methods such as imitation or interaction, and test the effectiveness of teaching on the basis of an active teaching atmosphere.

Fifth, innovative teaching models stimulate learning enthusiasm. In the national music teaching curriculum, higher vocational music teachers should focus on the effective combination of knowledge, interaction and interest. This is because the single teaching method will make students feel too monotonous, which is not conducive to their enthusiasm for music learning. The promotion. This will require constant innovation in teaching methods, enhance teacher-student interaction and other related links, creating a more pleasant and cheerful teaching atmosphere, so as to enhance the effectiveness of national music teaching and promote the quality of the national music culture of vocational college students. As for the innovation model, we can learn from the teaching methods of modern micro-classes. The role played by micro-classes in the classroom is very significant. By reducing the continuous renovation in the teaching content, some video content suitable for national music education can be used in the classroom. Play in. Of course, when assessing students, they should not be limited to the final exams. Instead, they should use the curriculum design to fully display their knowledge of the national music knowledge. This can improve the overall national music for the students of higher vocational education. The effectiveness of learning.

The sixth is to infiltrate national music into the daily life of vocational students. The education of ethnic music for vocational students should not be restricted to classroom education. It should also be permeated into the daily life of students. The national music education has cultivated students' sentiments, and the students' aesthetic ability has certainly achieved considerable results. The students' ability to promote their abilities, such as morality, intelligence, and beauty, has been fully exerted. The key talents for the modernization of the motherland are compound talents, and the patriotism spirit is an important guarantee for high-quality talents. The first-class national music learning situation is the basis for the students to learn. Therefore, based on the differences in the interest groups of the students, it is necessary to regularly carry out competition activities related to the national music culture.

\section{Summary}

In summary, the introduction of national music education in the music education of higher vocational schools in our country is indeed necessary. In order to improve the quality of national music teaching in higher vocational schools in China as much as possible, we should further deepen the awareness of national music education, continuously improve learners' enthusiasm for learning, establish a professional music teacher talent team, and develop a nation that is compatible with the actual conditions of higher vocational students. Music education activities. Therefore, in the next step, the music educators in higher vocational colleges should be advancing with the times and in-depth exploration of the establishment of characteristic ethnic music approach to student education, so that the national music education in vocational colleges can be improved. Take it one step higher.

\section{References}

[1] Chen Jinshi. An Analysis of the Role of Music Education in Cultivating Higher Vocational Students' Comprehensive Quality, Journal of Nanchang College of Education, 2013(7).

[2] Xi Xiangyang. Survey and Strategy on Musical Qualities of Higher Vocational Students_—On the Necessity of Improving Higher Vocational Students' Musical Quality, Journal of Kaifeng College of Education, 2014(8).

[3] Zhou Qi, Wang Liuding. The Necessity of Strengthening Vocational College Students' Traditional Cultural Music Education, Young Writers, 2013(9). 
[4] Ma Shuhao, Liu Hui. The Practice of Minority Musical Culture in Music Class in Colleges and Universities, Heilongjiang Higher Education Research, 2016(3).

[5] Peng Ying. Exploration and Practice of Integrating Traditional Music Culture into Vocational Vocal Music Teaching, Journal of Suzhou Education College, 2016(4). 